\title{
A Marine Bacterium, Bacillus sp. Isolated from the Sediment Samples of Algoa Bay in South Africa Produces a Polysaccharide-Bioflocculant
}

\author{
Ncedo Ntozonke ${ }^{1,2}$, Kunle Okaiyeto ${ }^{1,2, *}$, Arinze S. Okoli ${ }^{3}$, Ademola O. Olaniran ${ }^{4}$, \\ Uchechukwu U. Nwodo ${ }^{1,2}$ and Anthony I. Okoh 1,2 \\ 1 SAMRC Microbial Water Quality Monitoring Centre, University of Fort Hare, Private Bag X1314, Alice 5700, \\ South Africa; nntozonke@ufh.ac.za (N.N.); unwodo@ufh.ac.za (U.U.N.); aokoh@ufh.ac.za (A.I.O.) \\ 2 Applied and Environmental Microbiology Research Group (AEMREG), Department of Biochemistry and \\ Microbiology, University of Fort Hare, Private Bag X1314, Alice 5700, South Africa \\ 3 GenØK-Centre for Biosafety, Forskningsparken i Breivika, Postboks 6418, 9294 Tromsø, Norway; \\ aso023@post.uit.no \\ 4 Department of Microbiology, School of Life Sciences, University of KwaZulu-Natal, Private Bag X54001, \\ Durban 4000, South Africa; olanirana@ukzn.ac.za \\ * Correspondence: kokaiyeto@ufh.ac.za; Tel.: +27-710-358-873
}

Received: 1 September 2017; Accepted: 25 September 2017; Published: 29 September 2017

\begin{abstract}
Bioflocculants mediate the removal of suspended particles from solution and the efficiency of flocculation is dependent on the characteristics of the flocculant. Apart from the merits of biodegradability and harmlessness, bioflocculants could be viable as industrially relevant flocculants as they are a renewable resource. Additionally, the shortcomings associated with the conventionally used flocculants such as aluminium salts and acrylamide polymers, which include dementia and cancer, highlight more the need to use bioflocculants as an alternative. Consequently, in this study a marine sediment bacterial isolate was screened for bioflocculant production. Basic local alignment search tools (BLAST) analysis of $16 \mathrm{~S}$ ribosomal deoxyribonucleic acid (rDNA) sequence of the bacterial isolate showed $98 \%$ similarity to Bacillus thuringiensis MR-R1. The bacteria produced bioflocculant optimally with inoculum size $(4 \% v / v)(85 \%)$, glucose $(85.65 \%)$ and mixed nitrogen source (urea, ammonium chloride and yeast extract) $(75.9 \%)$ and the divalent cation $\left(\mathrm{Ca}^{2+}\right)(62.3 \%)$. Under optimal conditions, a maximum flocculating activity of over $85 \%$ was attained after $60 \mathrm{~h}$ of cultivation. The purified polysaccharide-bioflocculant flocculated optimally at alkaline $\mathrm{pH} 12(81 \%)$, in the presence of $\mathrm{Mn}^{2+}(73 \%)$ and $\mathrm{Ca}^{2+}(72.8 \%)$. The high flocculation activity shown indicates that the bioflocculant may contend favourably as an alternative to the conventionally used flocculants in water treatment.
\end{abstract}

Keywords: marine environment; Bacillus sp.; bioflocculants; polysaccharide; flocculation

\section{Introduction}

Flocculation is a process whereby suspended particles are agglomerated into larger floc. Flocculation processes have applications in pharmaceutical, dredging, dairy, fermentation, and other downstream processes [1]. Flocculating agents are grouped into inorganic, organic and biologicallyderived flocculants termed bioflocculants [2]. Inorganic and organic synthetic flocculants include aluminium sulphate, polyaluminum chloride, and derivatives of acrylamide and imine polymers which have dominated and, continue to dominate as flocculation mediators in the flocculation stage of water treatment processes [2-4].

These flocculating agents are noted as cost-effective and they mediate flocculation with high efficiency hence, their dominance as the conventionally used flocculants. Nonetheless, an associated 
shortfall has been their implication in Alzheimer's disease [5], cancer and other debilitating illnesses [6,7]. Additionally, the polymers of acrylamide and imine are recalcitrant to biodegradation [8], with all degradation attempts resulting in the reduction of the polymers to monomeric units which eventually may percolate into sediments or water beds and perhaps, seep into underground waters [9]. The presence of monomeric units of acrylamide and imine polymer derivatives in the environment, constitutes a serious public health concern [10].

Conversely, bioflocculants have not been associated with any adverse effects [11-13]. The enormous advantages associated with bioflocculants makes them interesting; although, industrial application with respect to the water treatment process has been limited by the generally low flocculating activity of bioflocculants from several microbial species, low bioflocculant yields, and the high cost of bioflocculant production $[8,14,15]$. The imperative of identifying bioflocculants has propelled the exploration of extreme environments seeking microbial species with enhanced bioflocculant production potential and as well with high flocculation efficiencies.

Several terrestrial and aquatic environments have been explored and microbes from various taxonomic genera including Streptomyces, Brachybacteria and Cellulomonas [9,16]; amongst the actinobacteria species Vagococcus, Arthrobacter, Scenedesmus and Bacillus [11,17-19], among others, have all been found to produce bioflocculants. The compositions of some of the identified bioflocculants have included polysaccharides, proteins, uronic acids, sugar conjugates and proteins [20-22]. The chemical compositions and flocculating efficiency of bioflocculants depends on some factors, including the nature of the environment in which bioflocculant-producing microorganisms were isolated, the media compositions in which the microorganisms are cultivated, the functional groups and molecular weight of the bioflocculant [23].

The marine environment remains a potential source of microbes with novel metabolites, and the exploitation of this ecosystem through searching for microbes with novel metabolites is still very important $[24,25]$. Therefore, the continued exploration of different habitats for novel microbial species with improved bioflocculant production potential has been a focus of research in this field. In this study, a bioflocculant-producing bacterial strain was isolated from sediment samples from the marine environment in the Eastern Cape, South Africa; the culture conditions influencing bioflocculant production was optimized and the bioflocculant produced was purified and characterized afterwards.

\section{Materials and Methods}

\subsection{Screening for Bioflocculant-Producing Bacteria}

Sediment samples were collected from Algoa Bay in the Eastern Cape Province of South Africa and processed according to the description of Jensen et al. [26] with some modifications. A wet sample $(0.5 \mathrm{~g})$ was diluted with sterile seawater $(5 \mathrm{~mL})$. The suspension was agitated and allowed to settle for $60 \mathrm{~s}$, then an aliquot of the upper phase $(100 \mu \mathrm{L})$ was inoculated onto the surface of R2A agar plates, spread with a sterile glass rod and incubated for $96 \mathrm{~h}$ at $28^{\circ} \mathrm{C}$. The distinct isolates were selectively picked and streaked onto nutrient agar plates to purify them. The bacterial isolate was activated by inoculating glycerol stock $(5 \mu \mathrm{L})$ into sterile broth $(5 \mathrm{~mL})$ composed of beef extract $(3 \mathrm{~g})$, tryptone $(10 \mathrm{~g})$ and $\mathrm{NaCl}(5 \mathrm{~g})$ in sterile filtered sea water $(1 \mathrm{~L})$, and incubated aerobically for $24 \mathrm{~h}$ at $28^{\circ} \mathrm{C}$ in a rotary shaker at $120 \mathrm{rpm}$. The growth medium was composed of glucose $(20 \mathrm{~g}), \mathrm{K}_{2} \mathrm{HPO}_{4}(5 \mathrm{~g}), \mathrm{KH}_{2} \mathrm{PO}_{4}(2 \mathrm{~g})$, $\mathrm{MgSO}_{4} \cdot 7 \mathrm{H}_{2} \mathrm{O}(0.3 \mathrm{~g})$, yeast extract $(0.5 \mathrm{~g})$, urea $(0.5 \mathrm{~g})$, and $\left(\mathrm{NH}_{4}\right)_{2} \mathrm{SO}_{4}(0.3 \mathrm{~g})$ in filtered marine water $(1 \mathrm{~L})$ [20]. A set of $500 \mathrm{~mL}$ flasks containing fermentation medium $(200 \mathrm{~mL})$ were aseptically inoculated with activated culture $2 \% v / v(4 \mathrm{~mL})$, after adjusting to cell density of about $1.5 \times 10^{8} \mathrm{CFU} / \mathrm{mL}$ and incubated at $28^{\circ} \mathrm{C}, 160 \mathrm{rpm}$ for $72 \mathrm{~h}$. After the cultivation period, the fermented broth was centrifuged (4000 rpm, $30 \mathrm{~min}, 15^{\circ} \mathrm{C}$ ) to separate the bacterial cells and the cell-free supernatant was assessed for flocculating activity [3]. 


\subsection{Determination of Flocculating Activity of Bioflocculant}

The flocculating activity was determined using the method described by Kurane et al. [27], in which Kaolin clay (Merck, Darmstadt, Germany) was chosen as the suspended solid. Culture supernatant $(2 \mathrm{~mL})$ and $\mathrm{CaCl}_{2}(3 \mathrm{~mL}, 1 \% w / v)$ were added into kaolin clay suspension $(100 \mathrm{~mL}$, $4 \mathrm{~g} / \mathrm{L}$ ) in a $250 \mathrm{~mL}$ flask, gently shaken and transferred into a $100 \mathrm{~mL}$ measuring cylinder and later left standing for $5 \mathrm{~min}$. The control was prepared following the same procedure but the bioflocculant was replaced by freshly prepared medium. The turbidity of the upper phase was measured with a spectrophotometer (Helios Epsilon, New York, NY, USA) at $550 \mathrm{~nm}$ and the flocculating activity was estimated as follows:

$$
\text { Flocculating rate }=\{(A-B) / A\} \times 100 \%
$$

where $A$ is the optical density of the control at $550 \mathrm{~nm}$; and $B$ is the optical density of the sample at $550 \mathrm{~nm}$. All experiments were performed in triplicates for the mean calculation. The bioflocculant-producing bacterial isolate was preserved in $20 \% v / v$ glycerol stock at $-80{ }^{\circ} \mathrm{C}$ as part of the culture collection of the Applied and Environmental Microbiology Research Group (AEMREG, University of Fort Hare, Alice, South Africa).

\subsection{Identification of Bioflocculant-Producing Bacteria}

The bioflocculant-producing bacterial isolate was identified by the molecular technique described by Cook and Mayers [28], and Nwodo et al. [2]. The bacterial 16S rDNA gene was amplified by polymerase chain reaction (PCR) followed by sequence analysis of the amplified gene. The bacterial DNA was extracted through the boiling method and the PCR amplification was carried out in $50 \mu \mathrm{L}$ reaction volume containing $2 \mathrm{mM} \mathrm{MgCl}_{2}$, 2 U Supertherm Taq polymerase, $150 \mathrm{mM}$ of each dNTP, $0.5 \mathrm{mM}$ of each primer (F1: 59-AGAGTTTGATCITGGCTCAG-39; I = inosine and primer R5:59-ACGGITACCTTGTTACGACTT-39) and $2 \mathrm{~mL}$ of the template DNA. Primer F1 and R5 bind to base positions 7-26 and 1496-1476 of the 16S DNA gene of Streptomyces ambofaciens ATCC23877, respectively [28]. The PCR conditions included the following steps: initial denaturation $\left(96{ }^{\circ} \mathrm{C}\right.$ for $2 \mathrm{~min}), 30$ cycles of denaturation $\left(96^{\circ} \mathrm{C}\right.$ for $\left.45 \mathrm{~s}\right)$, annealing $\left(56^{\circ} \mathrm{C}\right.$ for $\left.30 \mathrm{~s}\right)$ and extension $\left(72{ }^{\circ} \mathrm{C}\right.$ for $2 \mathrm{~min}$ ), and a final extension $\left(72{ }^{\circ} \mathrm{C}\right.$ for $5 \mathrm{~min}$ ). Gel electrophoresis of PCR products was carried out on $1 \%$ agarose gels to confirm that a fragment of the correct size had been amplified. Automated sequencing of the $16 \mathrm{~S}$ rDNA gene of the bacterial isolate was performed using the SCE2410 genetic analysis system (Spectrumedix, Fullerton, CA, USA,) equipped with 24 capillaries. The sequencing reactions were performed according to the manufacturer's instructions, using the Big Dye version 3.1 dye terminator cycle sequencing kit (Applied Biosystems, Foster city, CA, USA) and 27 F primer (5'-AGAGTTTGA TCMTGGCTCAG-3'). The sequences were edited manually based on the most similar sequences, and the results obtained were aligned with published 16S rDNA sequences in the GenBank through a BLAST sequence tool from the National Centre for Biotechnology Information (NCBI) Database (https:/ / www.ncbi.nlm.nih.gov).

\subsection{Effect of Inoculum Size on Bioflocculant Production}

Inoculum sizes of $1 \%(0.5 \mathrm{~mL}), 2 \%(1.0 \mathrm{~mL}), 3 \%(1.5 \mathrm{~mL}), 4 \%(2.0 \mathrm{~mL})$ and $5 \%(2.5 \mathrm{~mL})(v / v)$ in $50 \mathrm{~mL}$ of fermentation medium were assessed for bioflocculant production. These cultures were incubated at $160 \mathrm{rpm}, 28^{\circ} \mathrm{C}$ for $72 \mathrm{~h}$. After the incubation period, $2 \mathrm{~mL}$ of the fermentation broth was centrifuged $\left(4000 \mathrm{rpm}, 30 \mathrm{~min}, 15^{\circ} \mathrm{C}\right)$ and the supernatant was assessed for flocculation activity [2].

\subsection{Effect of Carbon, Nitrogen and Cation Sources on Bioflocculant Production}

To examine the effect of carbon, nitrogen and cation sources on bioflocculant production, carbon, nitrogen and cation sources were varied to test their effect. The carbon sources $(20 \mathrm{~g} / \mathrm{L})$ investigated were; glucose, sucrose, fructose, starch, lactose and maltose while the nitrogen sources $(1.3 \mathrm{~g} / \mathrm{L})$ assessed were; ammonium chloride, urea, tryptone, peptone and yeast extract and $\mathrm{Al}^{3+}, \mathrm{Fe}^{3+}, \mathrm{K}^{+}$, 
$\mathrm{Na}^{+}, \mathrm{Li}^{+}, \mathrm{Mg}^{2+}$ and $\mathrm{Mn}^{2+}$ at the concentration $(0.3 \mathrm{~g} / \mathrm{L})$ were used individually to replace $\mathrm{Mg}^{2+}$ in the basal salt medium used for screening the bacteria for bioflocculant production. The assessments were conducted in accordance to the method described by Lachhwani [29].

\subsection{Effect of Initial Medium $\mathrm{pH}$ on Bioflocculant Production}

To assess the effect of initial medium $\mathrm{pH}$ on bioflocculant production, $50 \mathrm{~mL}$ fermentation medium contained in $250 \mathrm{~mL}$ capacity flasks were adjusted with $0.1 \mathrm{M} \mathrm{NaOH}$ and $0.1 \mathrm{M} \mathrm{HCl}$ to $\mathrm{pH}$ values 2-12. Each flask was aseptically inoculated with activated culture $(2 \mathrm{~mL}) 4 \%(v / v)$ of fermentation medium. These cultures were incubated at $160 \mathrm{rpm}, 28^{\circ} \mathrm{C}$ for $72 \mathrm{~h}$.

\subsection{Time Course of Bioflocculant Production}

For the time course experiments, an optimum medium composition was used, which included glucose $(20 \mathrm{~g}), \mathrm{K}_{2} \mathrm{HPO}_{4}(5 \mathrm{~g}), \mathrm{KH}_{2} \mathrm{PO}_{4}(2 \mathrm{~g}), \mathrm{NaCl}(0.3 \mathrm{~g})$, yeast extract $(0.5 \mathrm{~g})$, urea $(0.5 \mathrm{~g})$, and $\left(\mathrm{NH}_{4}\right)_{2} \mathrm{SO}_{4}(0.3 \mathrm{~g})$ in filtered marine water $(1 \mathrm{~L})$ [3].

Saline solution $(50 \mathrm{~mL}, 0.85 \%$ ) was used to prepare the suspension of the bacterial isolate. The optical density was measured by taking the suspension $(100 \mu \mathrm{L})$ in distilled water $(1 \mathrm{~mL})$ and gradually readjusting the $\mathrm{OD}_{660}$ to 0.1 [20]. The standardized bacterial suspension $(4 \mathrm{~mL})$ was inoculated into production medium $(200 \mathrm{~mL})$ contained in $500 \mathrm{~mL}$ flasks and incubated in a rotary shaker at $160 \mathrm{rpm}, 28^{\circ} \mathrm{C}$ for over $80 \mathrm{~h}$. At $24 \mathrm{~h}$ intervals, an aliquot of the fermented broth $(10 \mathrm{~mL})$ was withdrawn and $2 \mathrm{~mL}$ of cell-free supernatant were used to determine the flocculating activity in accordance with the method of Kurane et al. [27]. The bacterial growth was monitored by measuring the optical density (OD) at $\mathrm{OD}_{660}$ and the bacterial counts were determined by a standard spread plate technique. The $\mathrm{pH}$ of the culture broth was also monitored simultaneously with a $\mathrm{pH}$ meter (Basic20 $\mathrm{pH}$ meter, Crison Instruments, Barcelona, Spain).

\subsection{Extraction and Purification of Bioflocculant}

Extraction and purification of the bioflocculant were carried out following the methods described elsewhere using media formulation based on the pre-determined optimum culture conditions [12]. After $60 \mathrm{~h}$ of fermentation, the fermented broth was centrifuged at $4000 \mathrm{rpm}$ for $30 \mathrm{~min}$. In order to remove insoluble substances $[13,17]$, one volume of sterile distilled water was added to the supernatant and centrifuged at $4000 \mathrm{rpm}$ for $30 \mathrm{~min}$. Subsequently, two volumes of ethanol were added to the supernatant and the mixture allowed standing at $4{ }^{\circ} \mathrm{C}$ overnight. The precipitate was collected by centrifugation $(4000 \times g$ for $15 \mathrm{~min})$, and vacuum dried. The crude extract was weighed and dissolved in $100 \mathrm{~mL}$ of distilled water and one volume of a mixed solution of chloroform and $n$-butyl alcohol $(5: 2 v / v)$ was added. The mixture was agitated for $60 \mathrm{~s}$ and left standing for $12 \mathrm{~h}$ at room temperature. The precipitate was re-suspended in $100 \mathrm{~mL}$ distilled water and later dialysed against distilled water overnight. Two volumes of ethanol were added to the dialyzed solution $(100 \mathrm{~mL})$ and the precipitate recovered was dissolved in $50 \mathrm{~mL}$ of distilled water and vacuum dried.

\subsection{Effect of Temperature, Cations and $\mathrm{pH}$ on the Flocculating Activity}

The flocculating activity of the purified bioflocculant was assessed using kaolin clay suspension as the test material to simulate the turbidity of surface water [27]. To evaluate the effect of temperature on flocculating activity of the bioflocculant, the bioflocculant solution $(2 \mathrm{~mL})$ was heated at different temperatures $\left(50,60,70,80\right.$ and $90{ }^{\circ} \mathrm{C}$ ) for $1 \mathrm{~h}$. The effect of $\mathrm{pH}$ on the flocculating activity was determined by varying the $\mathrm{pH}$ of the kaolin clay suspension from 3 to 12 . Similarly, the cation sources were varied as well from monovalent cations $\left(\mathrm{K}^{+}, \mathrm{Na}^{+}\right.$and $\left.\mathrm{Li}^{+}\right)$, divalent cations $\left(\mathrm{Mg}^{2+}, \mathrm{Mg}^{2+}\right.$ and $\left.\mathrm{Mn}^{2+}\right)$, and trivalent cations $\left(\mathrm{Al}^{3+}\right.$ and $\left.\mathrm{Fe}^{3+}\right)$, all other parameters were kept constant [30]. 


\subsection{Characterization of Purified Bioflocculant}

The protein content of the purified bioflocculant was determined using the Bradford method [31]. Total sugar content was measured using the phenol-sulphuric acid protocol as described by Chaplin and Kennedy [32].

\subsection{Statistical Analysis}

All data were treated in replicates and the standard deviation of the mean values was taken. Data were subjected to one-way analysis of variance (ANOVA) using MINITAB Student Release 12 statistical package for Windows 95/98 NT (Minitab Inc., State College, PA, USA, 2007).

\section{Results and Discussion}

\subsection{Screening and Identification of Bioflocculant-Producing Bacteria}

The bacteria used in this study were isolated from sediment samples of Algoa Bay in the Eastern Cape of Province, South Africa that were screened for bioflocculant production by investigating their potential to flocculate a kaolin clay suspension. The bacteria showed good bioflocculant production potential with a flocculating activity of over $60 \%$ for kaolin clay suspension. Furthermore, the nucleotide sequence of its $16 \mathrm{~S}$ rDNA gene showed $98 \%$ similarity to Bacillus thuringiensis MR-R1. Subsequently, the production of bioflocculant by the test bacteria was optimized through medium compositions and fermentation conditions.

\subsection{Effect of Inoculums Size on Bioflocculant Production}

The effects of different inoculum sizes on bioflocculant production by Bacillus sp. was investigated. Inoculum sizes of $1 \%, 2 \%, 3 \%, 4 \%$ and $5 \%(v / v)$ production medium were assessed, representing 0.5 , 1.0, 1.5, 2.0 and $2.5 \mathrm{~mL}$ in $50 \mathrm{~mL}$, respectively. From Figure 1, it can be observed that the bioflocculant production by the tested strain (Bacillus sp.) was inoculum size-dependent, with the highest flocculating activity $(85.1 \%)$ attained at $4 \%(v / v)$.

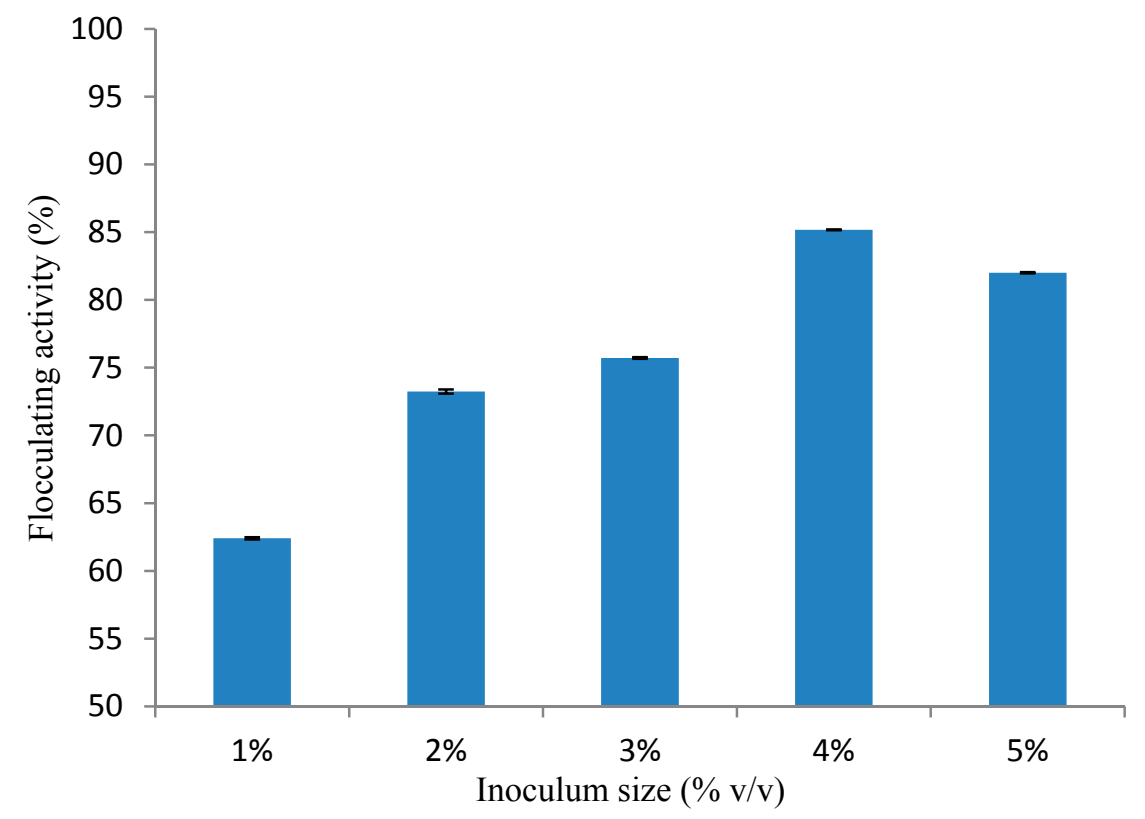

Figure 1. Effect of Inoculum Size on Bioflocculant Production by Bacillus sp.

After the optimum inoculum size was reached, any further increase in inoculum size resulted into a decrease in the flocculating activity, hence, inoculum size of $4 \%(v / v)$ was used in the subsequent 
experiments. Previous studies have proven that inoculum size plays an essential role in bioflocculant production, as a small inoculum size prolongs the lag phase during growth, whereas too large an inoculum size make the niche of strains overlap and restrains bioflocculant production due to the limit of nutrient allocation [33].

On the other hand, our present findings did not match previous studies. For example, a bioflocculant produced by Virgibacillus species was produced optimally at an inoculum size of $2 \%(v / v)$ [20], while, an inoculum size of $5 \%(v / v)$ was observed to be optimal for bioflocculant production by Klebsiella mobilis strain [34]. Xiong et al. [15] and Makapela et al. [22] observed the same phenomenon where Bacillus licherniformis and Bacillus pumilus optimally produced a bioflocculant at an inoculum size of $4 \%(v / v)$.

\subsection{Effect of Carbon, Nitrogen and Cation Sources on Bioflocculant Production}

The ability of bacteria to produce secondary metabolites could be influenced by the media composition and fermentation conditions [4]. Since the carbon source plays a very significant role in growth, particularly in extracellular polysaccharide production. Hence, in this present study, various carbon sources were assessed in order to improve the bioflocculant production. Table 1 shows the effect of various carbon sources on bioflocculant production. Glucose was observed to be the best carbon source for bioflocculant production by the tested strain (Bacillus sp.) with a flocculating activity of $85.65 \%$, followed by sucrose (60.6\%). On the other hand, lactose, maltose and starch poorly supported bioflocculant production with flocculating activities of $22.45 \%, 18.5 \%$ and $10.2 \%$, respectively. Hence, glucose was used in the subsequent experiments. From our findings, we observed that though a fructose-containing medium supported bacteria growth it was unable to activate the gene implicated in bioflocculant production and hence, no flocculating activity was observed compared with glucose-containing medium.

Glucose has been well documented in previous studies as the best organic sole carbon source [20]. For example, Streptomyces sp. Gansen produced bioflocculant optimally when glucose was the sole carbon source [2]. Furthermore, numerous bioflocculant-producing bacteria such as Serratia ficaria species and a mixed culture of Methylobacterium sp. Obi and Actinobacterium sp. Mayor prefer organic carbon sources for bioflocculant production [35,36]. On the contrary, Zhang et al. [3] revealed that glucose inhibited cell growth in Sorangium cellulosum during bioflocculant production.

Nitrogen sources play a crucial role in the production of bioflocculants [4]. The effect of organic, inorganic or combined nitrogen sources (urea, $\left(\mathrm{NH}_{4}\right)_{2} \mathrm{SO}_{4}$ and yeast extract) on bioflocculant production by the tested strain (Bacillus sp.) was examined. Among the sole nitrogen sources, peptone had the highest flocculating activity of $63.6 \%$. However, the combined nitrogen sources gave the highest activity of $75.9 \%$. Low flocculation rates were observed on media supplemented with yeast extract $(33 \%)$, urea $(27.7 \%)$ and $\left(\mathrm{NH}_{4}\right)_{2} \mathrm{SO}_{4}(35.25 \%)$. In agreement with our findings, Cosa et al. [20] observed that complex nitrogen substrate consisting of urea, yeast extract and $\left(\mathrm{NH}_{4}\right)_{2} \mathrm{SO}_{4}$ enhanced bioflocculant production than the other sole nitrogen sources tested. Okaiyeto et al. [4] reported that higher flocculating activity $(86.35 \%)$ was obtained when mixed nitrogen sources was used for bioflocculant production by Bacillus sp. AEMREG7, whereas, Gong et al. [35] observed 97\% flocculating activity from the bioflocculant produced by Serratia ficaria in beef extract and urea supplemented medium as nitrogen source. In this present study, on optimizing the media compositions, we observed that alteration in the carbon (glucose) and nitrogen sources [urea + yeast extract $+\left(\mathrm{NH}_{4}\right)_{2} \mathrm{SO}_{4}$ ] in the initial screening medium with complex nitrogen source (urea, yeast extract and $\left.\left(\mathrm{NH}_{4}\right)_{2} \mathrm{SO}_{4}\right)$ and glucose as sole carbon source, was used in subsequent experiments because alteration in the media composition decreased the bioflocculant production by the test bacteria.

The effect of different cations on bioflocculant production was investigated and out of eight cation sources tested, $\mathrm{Ca}^{2+}, \mathrm{Mn}^{2+}$ and $\mathrm{Al}^{3+}$ enhanced bioflocculant production with the following activities: $62.3 \%, 65.1 \%$ and $69.8 \%$, respectively. 
Table 1. Effect of Carbon, Nitrogen and Cation Sources on Bioflocculant Production by Bacillus sp.

\begin{tabular}{|c|c|c|c|c|c|c|c|c|}
\hline Carbon Source & Fructose & Sucrose & Maltose & Glucose & Lactose & Starch & & \\
\hline FA (\%) & - & $60.6 \pm 0.7$ & $18.5 \pm 0.9$ & $85.65 \pm 1.0$ & $22.45 \pm 2.0$ & $10.2 \pm 1.5$ & & \\
\hline Nitrogen Source & Peptone & Urea & Yeast extract & Tryptone & $\left(\mathrm{NH}_{4}\right)_{2} \mathrm{SO}_{4}$ & Combined & & \\
\hline FA $(\%)$ & $63.6 \pm 2.8$ & $27.7 \pm 2.9$ & $33 \pm 3.2$ & $22.1 \pm 1.8$ & $35.25 \pm 0.5$ & $75.9 \pm 1$ & & \\
\hline Cations & $\mathrm{Fe}^{3+}$ & $\mathrm{Al}^{3+}$ & $\mathrm{Ca}^{2+}$ & $\mathrm{Mn}^{2+}$ & $\mathrm{Mg}^{2+}$ & $\mathrm{Li}^{+}$ & $\mathrm{Na}^{+}$ & $\mathrm{K}^{+}$ \\
\hline FA (\%) & $5 \pm 0.9$ & $69.8 \pm 2.8$ & $62.3 \pm 3.1$ & $65.1 \pm-$ & $61.1 \pm 1.1$ & $23.9 \pm 2$ & $13 \pm 2.8$ & $13 \pm 2.8$ \\
\hline
\end{tabular}

FA represents flocculating activity and combined nitrogen source (Urea $+\left(\mathrm{NH}_{4}\right)_{2} \mathrm{SO}_{4}+$ yeast extract).

\subsection{Time Course of Bioflocculant Production}

Several factors influence bioflocculant production and thereby influence the flocculation process. These factors include: culture time, cell growth and $\mathrm{pH}$. Amongst these factors culture time may influence the production, distribution and flocculating capabilities of the bioflocculant [12]. Although, culture time for flocculant release into the medium and its activity may differ with different microorganisms, most are produced biosynthetically. Optimum culture conditions were used for the time course experimentation over $80 \mathrm{~h}$ of cultivation period (Figure 2).

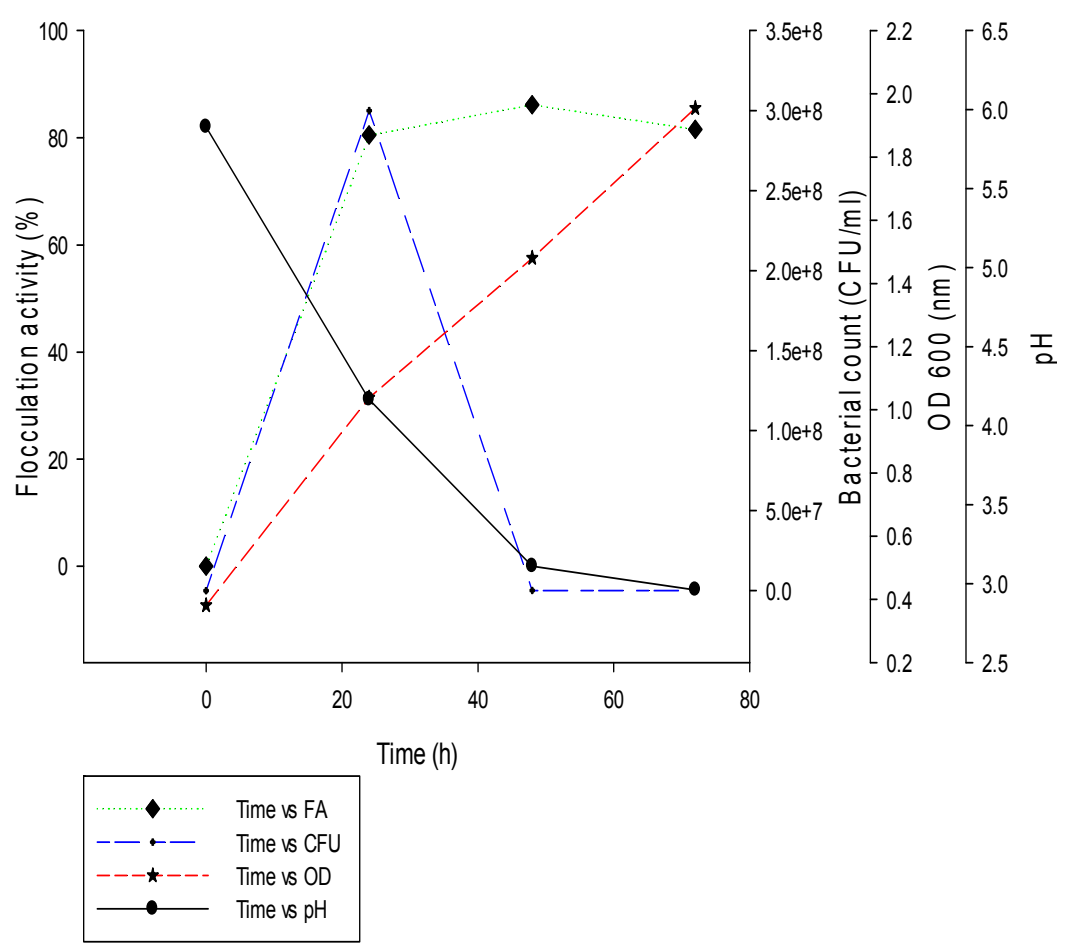

Figure 2. Time Course Profile of Bioflocculant Production by Bacillus sp.

There was a rapid exponential increase in bioflocculant production starting from the first $24 \mathrm{~h}$ and subsequently reached a peak after $60 \mathrm{~h}(85 \%)$ at $\mathrm{pH} 3$. Thereafter, a decline or levelling of cell growth (bacterial counts) was observed and thus, this decline may be due to cell autolysis and enzymatic activity [14]. From the cell growth curve pattern, it was observed that the cell growth was parallel to the flocculating activity from 0 to $24 \mathrm{~h}$. This indicates that the bioflocculant was produced during the growth of the bacteria not by cell autolysis [22]. A gradual decrease in $\mathrm{pH}$ was observed from 5.89 after $24 \mathrm{~h}$ to 2.96 after $72 \mathrm{~h}$. The decrease in $\mathrm{pH}$ with increase in cultivation time may be due to the production of organic acids from the metabolism of glucose or due to the production of organic acid as part of the components of the produced bioflocculant [17]. A slow decrease in flocculating activity was observed after $60 \mathrm{~h}$ of incubation, this observed decrease in activity may be attributed to the action of a bioflocculant-degrading enzyme being produced by the microorganism. Similarly, Piyo et al. [37] observed the same phenomenon whereby Bacillus sp. Gilbert 
produced a bioflocculant with flocculating activity increasing with the increase of cultivation time. The same phenomenon was observed by Cosa et al. [12] where Virgibacillus sp. Rob showed highest flocculating activity at day 4 . Furthermore, Cobetia sp. produced a bioflocculant during the exponential phase [38]. After $60 \mathrm{~h}$ of incubation, flocculating activity began to decrease, while cell growth decreased gradually after $50 \mathrm{~h}$. The decrease in flocculating activity is due to cell autolysis and/or presence of a bioflocculant-degrading enzyme [20,38].

\subsection{Factors Affecting Flocculating Activity of the Purified Bioflocculant}

\subsubsection{Effect of Bioflocculant Dosage}

The appropriate bioflocculant dosage to be used for subsequent experiments was determined by investigating different bioflocculant dose ranging from 0.1 to $0.5 \mathrm{mg} / \mathrm{mL}$ (Figure 3). The aim of the bioflocculant dosage experiment was to determine the lowest bioflocculant concentration to be used while attaining the highest flocculating efficiency $[19,22]$. Bioflocculant dosage is strain dependant and hence, bioflocculant produced in this present study attained an optimal activity at $0.5 \mathrm{mg} / \mathrm{mL}$.

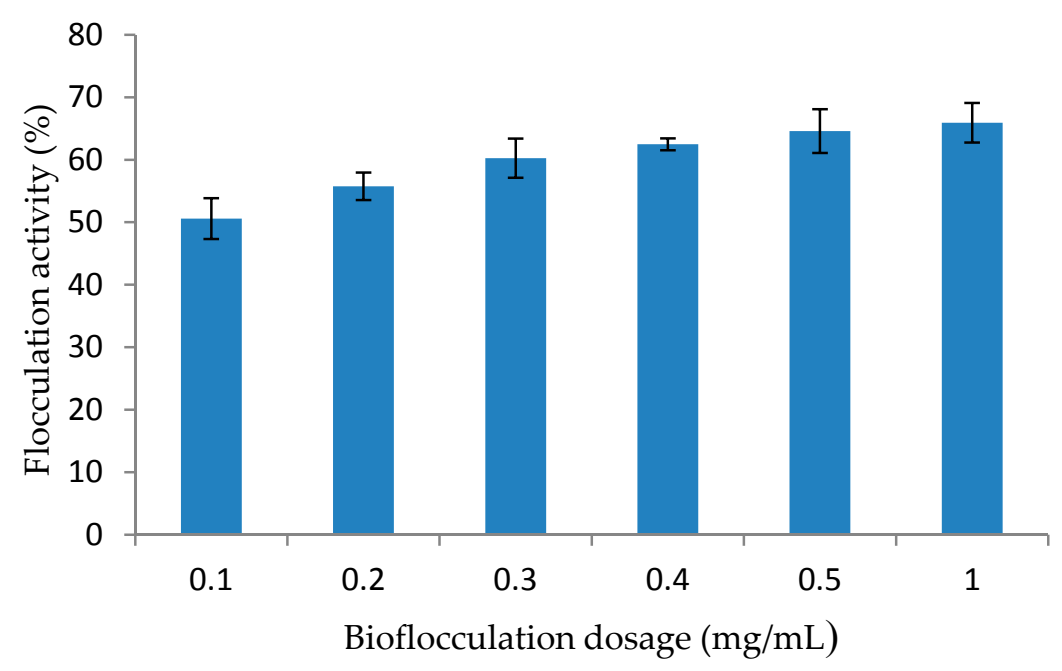

Figure 3. Effect of Bioflocculant Dosage on Flocculating Activity of the Purified Bioflocculant.

Contrary to our present findings, Okaiyeto et al. [13] reported optimal flocculating activity at $0.1 \mathrm{mg} / \mathrm{mL}$ by a bioflocculant produced by a consortium of Halomonas sp. Okoh and Micrococcus sp. Leo. Ntsaluba et al. [36] documented a dosage of $2 \mathrm{mg} / \mathrm{mL}$ for bioflocculant produced by a consortium of Methylobacterium sp. Obi and Actinobacterium sp. Mayor, while Wang et al. [39] found that a mixed culture of Rhizobium radiobacter F2 and Bacillus sphaeicus F6 produced a bioflocculant which had a maximum activity $(96.21 \%)$ at $12 \mathrm{mg} / \mathrm{mL}$. These results revealed that the bioflocculant produced by Bacillus sp. showed high flocculating activity at very low dosage, which should be beneficial to industrial scale applications as low dosage reduce treatment costs [22]. In case of bioflocculant (MBF-W7) produced by Bacillus sp., the highest flocculating activity was observed at $0.2 \mathrm{mg} / \mathrm{mL}$; subsequently, the flocculation rate decreased below or above this dosage value [40].

\subsubsection{Effect of Cation and Temperature on the Flocculating Activity of the Purified Bioflocculant}

As a strategy to produce biofloculants in a large industrial scale, it is highly imperative to isolate bacteria with high bioflocculant-producing capability as well as with high flocculating efficiency [4]. Cations play a crucial role in the flocculation efficacy of a bioflocculant. Cations have the ability to neutralize negatively charged functional groups of both bioflocculant molecules and suspended particles, thereby increasing the adsorption of the bioflocculant onto the suspended particles [4]. 
In this present study, out of eight cations investigated, only $\mathrm{Mn}^{2+}$ and $\mathrm{Fe}^{3+}$ inhibited flocculation among others. From Table 2, $\mathrm{Al}^{3+}, \mathrm{Ca}^{2+}$ and $\mathrm{Mg}^{2+}$ had the highest flocculating with $73.9 \%$, $72.8 \%$ and $70.9 \%$, respectively. Aluminium salts have been frequently used in drinking water and wastewater treatment due to their high flocculating efficiency and cost-effectiveness. Nevertheless, residual aluminium concentrations in treated water impose health problems [21]; consequently, in this present study, $\mathrm{Ca}^{2+}$ was used as a flocculation aid. Furthermore, Nwodo and Okoh [16] reported similar findings by Cellulomonas sp. Okoh. The flocculating activity of bioflocculant produced by Bacillus sp. AEMREG7 was greatly enhanced in the presence of $\mathrm{Ca}^{2+}$ as well [21]. Valence plays a crucial role in the flocculation efficiency, as observed by Okaiyeto et al. [13], the flocculating activity of the bioflocculant produced by Halomonas sp. and Micrococcus sp. optimally flocculated in the presence of $\mathrm{Al}^{3+}$ and $\mathrm{Ca}^{2+}$.

Table 2. Effect of Temperature and Cation on the Flocculating Activity of Purified Bioflocculant.

\begin{tabular}{|c|c|c|c|c|c|c|c|c|}
\hline $\operatorname{Temp}\left({ }^{\circ} \mathrm{C}\right)$ & 50 & 60 & 70 & 80 & 90 & & & \\
\hline FA (\%) & $66.6 \pm 0.64$ & $70 \pm 1.2$ & $70.8 \pm 0.0$ & $72.2 \pm 1.5$ & $69.4 \pm 2.3$ & & & \\
\hline Cations & $\mathrm{Al}^{3+}$ & $\mathrm{Fe}^{3+}$ & $\mathrm{Ca}^{2+}$ & $\mathrm{Mn}^{2+}$ & $\mathrm{Mg}^{2+}$ & $\mathrm{K}^{+}$ & $\mathrm{Li}^{+}$ & $\mathrm{Na}^{+}$ \\
\hline FA (\%) & $73.9 \pm 3.4$ & $8.7 \pm 6.8$ & $72.8 \pm 4.3$ & - & $70.9 \pm 2.1$ & $65 \pm 0.8$ & $57.3 \pm 2.6$ & $57.2 \pm 3.9$ \\
\hline
\end{tabular}

In most studies reported in the literature, flocculation processes have been enhanced with cations of high valence, as they stimulate more flocculation by neutralizing and forming bridges that bind kaolin [41]. In this present study, it was observed that flocculating activity was more enhanced by trivalent and divalent cations except for $\mathrm{Mn}^{2+}$ and $\mathrm{Fe}^{3+}$ (Table 2). Li et al. [24] emphasized that cations have the ability to neutralize negatively charged functional groups of both bioflocculant molecules and suspended particles, thereby increasing the adsorption of the bioflocculant onto the suspended particles, hence, monovalent cations weakly neutralize these negative charges in comparison to cations of higher valences. $\mathrm{Fe}^{3+}$ might possibly alter the surface charge of kaolin surfaces and cover the adsorb sites. The competition of the positively charged particles and less adsorb sites might induce the antagonist effect of $\mathrm{Fe}^{3+}$ that resulted into poor flocculation [42]. This implies that the electrostatic repulsive forces between $\mathrm{Fe}^{3+}$ and charged groups of the bioflocculant will be higher as compared with divalent cations and $\mathrm{Al}^{3+}$ and this consequently leads to the inhibition of flocculating activity of the bioflocculant in the presence of $\mathrm{Fe}^{3+}$. Excessive adsorption of the ions might be the cause of inhibition of the flocculation process in the presence of $\mathrm{Fe}^{3+}$ [42].

The thermal stability of bioflocculant is an important property for its commercial exploitation. Several studies have documented different organisms that produced thermal stable bioflocculants [13,43-46]. The thermal stability of the purified bioflocculant was examined at 50, 60,70,80, and $90^{\circ} \mathrm{C}$ for $1 \mathrm{~h}$ at each temperature. Table 2 shows the effect of temperature on flocculating activity of the bioflocculant produced by Bacillus sp. The bioflocculant showed permanence to heat as an increase in flocculating activity was observed up to $90^{\circ} \mathrm{C}$. Okaiyeto et al. [40] reported that the exhibition of thermal stability by bioflocculants may be characteristic of their polysaccharide backbone.

\subsubsection{Effect of $\mathrm{pH}$ on Flocculating Activity of Purified Bioflocculant}

Flocculating activity of purified bioflocculant was greatly influenced by change in $\mathrm{pH}$ of the reaction mixture. It was observed that the highest flocculation rate was at the extremes, with maximum activity at $\mathrm{pH} 12$ (81.25\%) (Figure 4). This implies that the bioflocculant can be used to treat or used at various $\mathrm{pH}$ ranges especially at acidic and alkaline conditions. The surface area of the purified bioflocculant increased in the extreme $\mathrm{pH}$ regimes and this aided its flocculation efficiency. In this current study, the bioflocculant produced by Bacillus sp. flocculated well over a wide range of $\mathrm{pH}$ values, the lowest being only $39 \%$ and $47 \%$. The decrease in flocculating activity between pH 6 and 7 , may be due to the hydroxyl ions $\left(\mathrm{OH}^{-}\right)$adsorbed at neutral medium ( $\mathrm{pH} 6$ and 7) may interfere 
with the complex formed between bioflocculant produced and the kaolin particles mediated by $\mathrm{Ca}^{2+}$, thereby resulting in destabilization of the suspended particles [40]. From our findings, pH stability of the purified bioflocculant portends good industrial applicability. Alteration of $\mathrm{pH}$ may perhaps ultimately alter the bioflocculant charge status and surface characteristics of suspended materials which consequently changes the flocculating ability [46]. The findings of Zaki et al. [47] collaborate with our results in which the purified bioflocculant MBF-5 produced by Klebsiella pneumonia maintained higher flocculating activity (90-95\%) under acidic condition ( $\mathrm{pH} 2-5)$ and alkaline condition ( $\mathrm{pH}$ 8-11). Contrary to our findings, Aljuboori et al. [48] observed that the bioflocculant IH-7 produced by Aspergillus flavus showed over $90 \%$ flocculating rate at a wide $\mathrm{pH}$ range of 3-7. The bioflocculant was only suitable at acidic and neutral conditions.

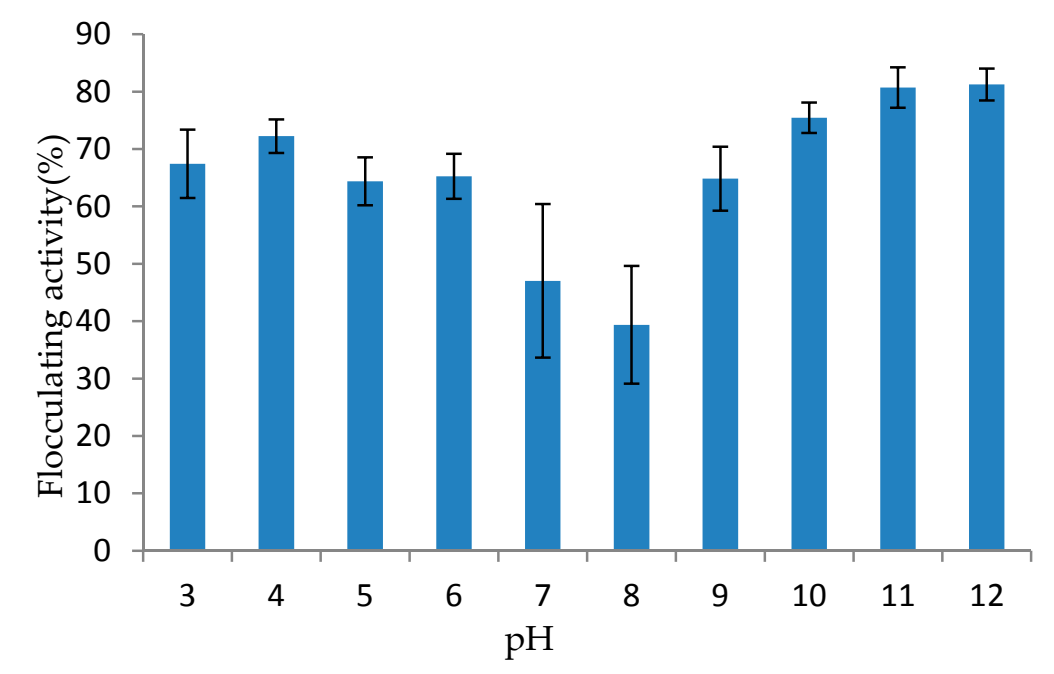

Figure 4. Effect of $\mathrm{pH}$ on Flocculating Activity of Bioflocculant Produced by the Tested Strain (Bacillus sp.).

\subsubsection{Fourier Transform Infrared (FTIR) Spectroscopy of the Purified Bioflocculant}

A broad stretching peak was observed at $3418.54 \mathrm{~cm}^{-1}$ which indicated the presence of hydroxyl and amine groups (Figure 5).

This may also be as a result of vibration of $\mathrm{OH}^{-}$or $\mathrm{NH}_{2}$ groups present in the sugar ring $[13,15]$, and the weak peaks at $844.90 \mathrm{~cm}^{-1}$ reveal the presence of sugar derivatives whereas, the one at $1460.62 \mathrm{~cm}^{-1}$ indicated the presence of uronate in the polysaccharide. The vibration peak at $1135.81 \mathrm{~cm}^{-1}$ corresponds to the C-O stretching in alcohols and this further suggests the presence of $\mathrm{OH}$ group in the bioflocculant molecule [2,43]. Peaks at 1637.65 and $1460.62 \mathrm{~cm}^{-1}$ from the polymeric and dimeric $\mathrm{OH}$ stretches of phenol or tertiary alcohol bends indicate the presence of carboxyl and hydroxyl groups. The strong absorption peak observed at $530.03 \mathrm{~cm}^{-1}$ is known to be a typical characteristic of sugar derivatives. The infrared spectrum of the bioflocculant thus indicated the presence of carboxyl, hydroxyl and amino groups which might be responsible for the high flocculating efficiency observed in this study [49]. 


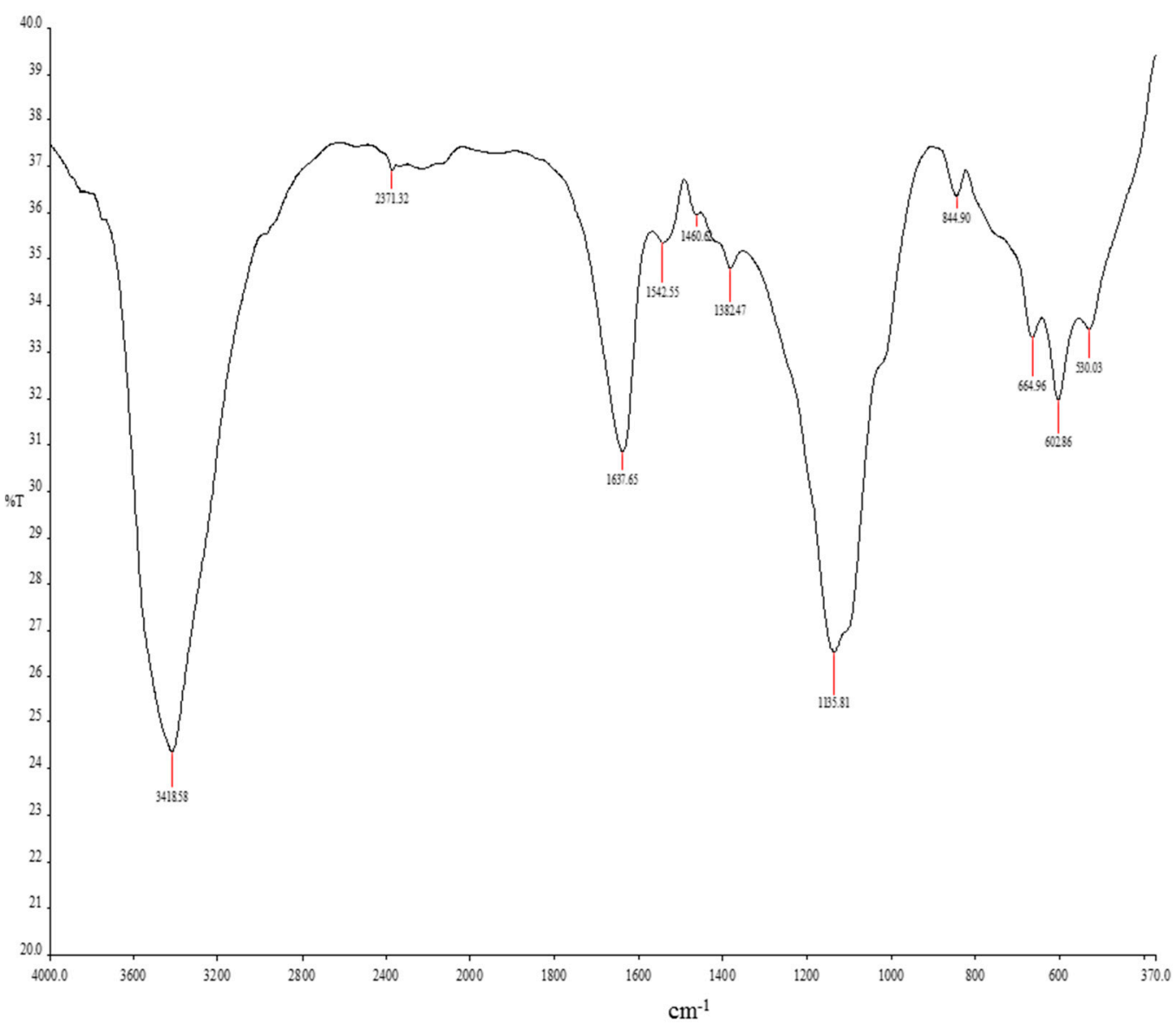

Figure 5. FTIR Spectroscopy of Purified Bioflocculant Produced by the Tested Strain (Bacillus sp.).

\section{Conclusions}

The adverse effects of chemical flocculants such as potential carcinogenicity, non-biodegradability, neurotoxicity and neurodegenerative effects, led us to explore the marine milieu seeking innocuous and biodegradable microbial flocculants. In this present study, a Bacillus sp. was isolated from the sediments of Algoa Bay in South Africa and its potential for bioflocculant production was investigated. The bacterium showed a flocculating activity over $60 \%$ on initial screening. The bioflocculant optimally flocculated when glucose, mixed nitrogen sources (yeast extract, urea, and $\left(\mathrm{NH}_{4}\right)_{2} \mathrm{SO}_{4}$ and $\mathrm{Ca}^{2+}$ were used as carbon, nitrogen and cation sources, respectively. The bioflocculant had strong flocculating activity over a wide range of $\mathrm{pH}$, both at acidic and alkaline $\mathrm{pH}$ values, with low dosage requirements. The flocculating activity of the bioflocculant was stimulated in the presence of $\mathrm{Ca}^{2+}$. The presence of hydroxyl, amino and carboxyl groups as the main functional groups in the molecular chain of the bioflocculant might be responsible for its high flocculating efficiency. This bioflocculant could serve an alternative to replace the harmful and non-degradable chemical flocculants that are widely used in wastewater treatment, hence, making it candidate for further research and possible development for industrial-scale application.

Acknowledgments: We are grateful to the National Research Foundation (NRF) of South Africa, South Africa Medical Research Council (SAMRC), South Africa-Norway Research Co-operation (SANCOOP), and University of Fort Hare for their supports toward this project.

Author Contributions: All authors contributed to the work presented in this paper, Ncedo Ntozonke executed the research and collated the data; Kunle Okaiyeto. drafted the first manuscript; Arinze S. Okoli interpreted the data and proofread the manuscript; Ademola O. Olaniran carried out the molecular identification of the bacterial species; Uchechukwu U. Nwodo supervised the research and Anthony I. Okoh conceptualized and designed the overall research. All authors read and approved the final manuscript. 
Conflicts of Interest: The authors declare no conflict of interest.

\section{References}

1. Abdel-Aziz, S.M.; Hoda, A.; Hamed, H.A.; Mouafi, F.A.; Nayera, A.M.; Abdelwahed, N.A.M. Extracellular Metabolites Produced by a Novel Strain, Bacillus alvei NRC-14: 3. Synthesis of a Bioflocculant That Has Chitosan-Like Structure. Life Sci. J. 2011, 8, 4.

2. Nwodo, U.U.; Agunbiade, M.O.; Green, E.; Mabinya, L.V.; Okoh, A.I. A freshwater Streptomyces, isolated from Tyume River, produces a predominantly extracellular glycoprotein bioflocculant. Int. J. Mol. Sci. 2012, 13, 8679-8695. [CrossRef] [PubMed]

3. Zhang, Z.; Lin, B.; Xia, S.; Wang, X.; Yang, A. Production and application of a novel bioflocculant by multi-microorganism consortia using brewery wastewater as carbon source. J. Environ. Sci. 2007, 19, 667-673. [CrossRef]

4. $\quad$ Okaiyeto, K.; Nwodo, U.U.; Okoli, A.S.; Mabinya, L.V.; Okoh, A.I. Implications for public health demands alternatives to inorganic and synthetic flocculants: Bioflocculants as important candidates. MicrobiologyOpen 2016, 5, 177-211. [CrossRef] [PubMed]

5. Ruden, C. Acrylamide and cancer risk-expert risk assessments and the public debate. Food Chem. Toxicol. 2004, 42, 335-349. [CrossRef] [PubMed]

6. He, N.; Li, Y.; Chen, J. Production of a novel polygalacturonic acid bioflocculant REA-11 by Corynebacterium glutamicum. Bioresour. Technol. 2004, 94, 99-105. [CrossRef] [PubMed]

7. Banks, W.A.; Niehoff, M.L.; Drago, D.; Zatta, P. Aluminum complexing enhances amyloid (protein penetration of blood-brain barrier. Brain Res. 2006, 20, 215-221. [CrossRef] [PubMed]

8. Salehizadeh, H.; Yan, N. Recent advances in extracellular biopolymer flocculants. Biotechnol. Adv. 2014, 32, 1506-1522. [CrossRef] [PubMed]

9. Nwodo, U.U.; Okoh, A.I. Mixed culture fermentation and media optimization by response surface model: Streptomyces and Brachybacterium species in bioflocculant production. Molecules 2014, 19, 11131-11144. [CrossRef] [PubMed]

10. Polizzi, S.; Pira, E.; Ferrara, M.; Buginani, M.; Papaleo, A.; Albera, R.; Palmi, S. Neurotoxic effects of aluminium among foundry workers and Alzheimer's disease. Neurotoxicology 2002, 23, 761-774. [CrossRef]

11. Mabinya, L.; Cosa, S.; Nwodo, U.; Okoh, A.I. Studies on bioflocculant production by Arthrobacter sp. Raats, freshwater bacteria isolated from Tyume River, South Africa. Int. J. Mol. Sci. 2012, 13, 1054-1065. [CrossRef] [PubMed]

12. Cosa, S.; Mabinya, L.V.; Olaniran, A.O.; Okoh, O.O.; Okoh, A.I. Bioflocculant production by Virgibacillus sp. Rob isolated from the bottom sediment of Algoa Bay in the Eastern Cape, South Africa. Molecules 2011, 16, 2431-2442. [CrossRef] [PubMed]

13. Okaiyeto, K.; Nwodo, U.U.; Mabinya, L.V.; Okoh, A.I. Characterization of a bioflocculant produced by a consortium of Halomonas sp. Okoh and Micrococcus sp. Leo. Int. J. Environ. Res. Public Health 2013, 10, 5097-50110. [CrossRef] [PubMed]

14. Li, Z.; Zhong, S.; Lei, H.; Chen, R.; Yu, Q.; Li, H. Production of a novel bioflocculant by Bacillus licheniformis X14 and its application to low temperature drinking water treatment. Bioresour. Technol. 2009, 100, 3650-3656. [CrossRef] [PubMed]

15. Xiong, Y.; Wang, Y.; Yu, Y.; Li, Q.; Wang, H.; Chen, R.; He, N. Production and characterization of a novel bioflocculant from Bacillus licheniformis. Am. Soc. Microbiol. 2010, 76, 9. [CrossRef] [PubMed]

16. Nwodo, U.U.; Okoh, A.I. Characterization and flocculation properties of biopolymeric flocculant (glycosaminoglycan) produced by Cellulomonas sp. Okoh. J. Appl. Microbiol. 2013, 114, 1325-1337. [CrossRef] [PubMed]

17. Gao, J.; Bao, H.Y.; Xin, M.X.; Liu, Y.X.; Li, Q.; Zhang, Y.F. Characterization of a bioflocculant from a newly isolated Vagococcus sp. W31. J. Zhejiang Univ. Sci. B 2006, 7, 186-192. (In Chinese) [CrossRef] [PubMed]

18. Kim, D.G.; La, H.J.; Ahn, C.Y.; Park, Y.H.; Oh, H.M. Harvest of Scenedesmus sp. with bioflocculant and reuse of culture medium for subsequent high-density cultures. Bioresour. Technol. 2011, 102, 3163-3168. [CrossRef] [PubMed] 
19. Okaiyeto, K.; Nwodo, U.U.; Mabinya, L.V.; Okoh, A.I. Bacillus toyonensis Strain AEMREG6, a bacterium isolated from South Africa marine environment sediment samples produces a glycoprotein bioflocculant. Molecule 2015, 20, 5239-5259. [CrossRef] [PubMed]

20. Cosa, S.; Ugbenyen, M.A.; Mabinya, L.V.; Okoh, I.A. Characterization of a thermostable polysaccharide bioflocculant produced by Virgibacillus species isolated from Algoa Bay. Afr. J. Microbiol. Res. 2013, 7, 2925-2938. [CrossRef]

21. Okaiyeto, K.; Nwodo, U.U.; Okoli, A.S.; Mabinya, L.V.; Okoh, A.I. Studies on bioflocculant production by Bacillus sp. AEMREG7. Pol. J. Environ. Stud. 2016, 25, 241-250. [CrossRef]

22. Makapela, B.; Okaiyeto, K.; Ntozonke, N.; Nwodo, U.U.; Green, E.; Mabinya, L.V.; Okoh, A.I. Assessment of Bacillus pumilus isolated from fresh water milieu for bioflocculant production. Appl. Sci. 2016, 6, 211. [CrossRef]

23. Liu, W.J.; Wang, K.; Li, B.Z.; Yuan, H.L.; Yang, J.S. Production and characterization of an intracellular bioflocculant by Chryseobacterium daeguense W6 cultured in low nutrition medium. Bioresour. Technol. 2010, 101, 1044-1048. [CrossRef] [PubMed]

24. Li, W.W.; Zhou, W.Z.; Zhang, Y.Z.; Wang, J.; Zhu, X.B. Flocculation behavior and mechanism of an exopolysaccharide from the deep-sea psychrophilic bacterium Pseudoalteromonas sp. SM9913. Bioresour. Technol. 2008, 99, 6893-6899. [CrossRef] [PubMed]

25. Mabrouk, M.E.M. Production of bioflocculant by the marine actinomycete Nocardiopsis aegyptia sp. nov. Life Sci. J. 2014, 11, 27-35.

26. Jensen, P.R.; Erin, G.; Chrisy, M.; Tracy, J.; Mincer, W.F. Culturable marine actinomycete diversity from tropical Pacific Ocean sediments. Environ. Microbiol. 2005, 7, 1039-1048. [CrossRef] [PubMed]

27. Kurane, R.; Hatamochi, K.; Kakuno, T.; Kiyohara, M.; Kawaguchi, K.; Mizuno, Y.; Hirano, M.; Taniguchi, Y. Purification and characterization of lipid bioflocculant produced Rhodococcus erythropolis. Biosci. Biotechnol. Biochem. 1994, 58, 1977-1982. [CrossRef]

28. Cook, A.E.; Meyers, P.R. Rapid identification of filamentous actinomycetes to the genus level using genus-specific 16S rRNA gene restriction fragment patterns. Int. J. Syst. Evol. Microbiol. 2003, 53, 1907-1915. [CrossRef] [PubMed]

29. Lachhwani, P. Studies on Polymeric Bioflocculant Producing Microorganisms. Master's Thesis, Thapar Institute of Engineering and Technology, Patiala, India, May 2007.

30. Yim, J.H.; Kim, S.J.; Ahn, S.H.; Lee, H.K. Characterization of a novel bioflocculant, p-KG03, from a marine dinoflagellate, Gyrodinium impudicum KG03. Bioresour. Technol. 2007, 98, 361-367. [CrossRef] [PubMed]

31. Bradford, M.M. A rapid and sensitive for the quantitation of microgram quantitites of protein utilizing the principle of protein-dye binding. Analyt. Biochem. 1976, 72, 248-254. [CrossRef]

32. Chaplin, M.F.; Kennedy, J.F. Carbohydrate Analysis, 2nd ed.; Oxford University Press: New York, NY, USA, 1994.

33. Salehizadeh, H.; Shojaosadati, S.A. Extracellular biopolymeric flocculants: Recent trends and biotechnological importance. Biotechnol. Adv. 2001, 19, 371-385. [CrossRef]

34. Wang, S.; Gonga, X.; Liu, X.; Tian, L.; Yue, Q.; Gao, B. Production of a novel bioflocculant by culture of Klebsiella mobilis using dairy wastewater. Biochem. Eng. J. 2007, 36, 81-86. [CrossRef]

35. Gong, W.X.; Wang, S.W.; Sun, X.F.; Liu, X.W.; Yue, Q.Y.; Gao, B.Y. Bioflocculant production by culture of Serratia ficaria and its application in wastewater treatment. Bioresour. Technol. 2008, 99, 4668-4674. [CrossRef] [PubMed]

36. Ntsaluba, L.; Nwodo, U.U.; Mabinya, L.V.; Okoh, A.I. Studies on bioflocculant production by a mixed culture of Methylobacterium sp. Obi and Actinobacterium sp. Mayor. BMC Biotechnol. 2013, 13, 62.

37. Piyo, N.; Cosa, S.; Mabinya, L.V.; Okoh, A.I. Assessment of bioflocculant production by Bacillus sp. Gilbert, a marine bacterium isolated from the bottom sediment of Algoa Bay. Mar. Drugs 2011, 9, 1232-1242.

38. Ugbenyen, A.; Cosa, S.; Mabinya, L.; Babalola, O.O.; Aghdasi, F.; Okoh, A. Thermostable bacterial bioflocculant produced by Cobetia sp. isolated from Algoa Bay (South Africa). Int. J. Environ. Res. Public Health 2012, 9, 2108-2120. [CrossRef] [PubMed]

39. Wang, L.; Ma, F.; Qu, A.; Sun, D.; Li, A.; Guo, J.; Yu, B. Characterization of a compound bioflocculant produced by mixed culture of Rhizobium radiobacter F2 and Bacillus sphaeicus F6. World J. Microbiol. Biotechnol. 2011, 27, 2559-2565. [CrossRef] 
40. Okaiyeto, K.; Nwodo, U.U.; Mabinya, L.V.; Okoli, A.S.; Okoh, A.I. Evaluation of flocculating performance of a thermostable bioflocculant produced by marine Bacillus sp. Environ. Technol. 2016, 37, 1829-1842. [CrossRef] [PubMed]

41. Okaiyeto, K.; Nwodo, U.U.; Mabinya, L.V.; Okoh, A.I. Evaluation of the flocculation potential and characterization of bioflocculant produced by Micrococcus sp. Leo. Appl. Biochem. Microbiol. 2014, 50, 601-608. [CrossRef]

42. Okaiyeto, K.; Nwodo, U.U.; Mabinya, L.V.; Okoli, A.S.; Okoh, A.I. Characterization of a bioflocculant (MBF-UFH) produced by Bacillus sp. AEMREG7. Int. J. Mol. Sci. 2015, 16, 12986-13003. [CrossRef] [PubMed]

43. Gao, Q.; Zhu, X.H.; Mu, J.; Zhang, Y.; Dong, X.W. Using Ruditapes philippinarum conglutination mud to produce bioflocculant and its applications in wastewater treatment. Bioresour. Technol. 2009, 100, 4996-5001. [CrossRef] [PubMed]

44. Wang, L.; Ma, F.; Lee, D.; Wang, A.; Ren, N. Bioflocculants from hydrolysates of corns stover using isolated strain Ochrobactium cicero W2. Bioresour. Technol. 2013, 145, 259-263. [CrossRef] [PubMed]

45. Ugbenyen, A.M.; Okoh, A.I. Characteristics of a bioflocculant produced by a consortium of Cobetia and Bacillus species and its application in the treatment of wastewaters. Water SA 2014, 40, 139-144. [CrossRef]

46. Zhang, H.; Lin, Z. Microbial flocculant and its application in environmental protection. J. Environ. Sci. 1999, $11,1-12$.

47. Zaki, S.A.; Marwa, F.; Elkady, S.F.; Desouky, A. Characterization and flocculation properties of a carbohydrate bioflocculant from a newly isolated Bacillus velezensis 40B. J. Environ. Biol. 2012, 34, 51-58.

48. Aljuboori, A.H.R.; Yoshimitsu, U.; Noridah, B.O.; Suzana, Y. Production of a bioflocculant from Aspergillus niger using palm oil mill effluent as carbon source. Bioresour. Technol. 2013, 171, 66-70. [CrossRef] [PubMed]

49. Liu, L.; Cheng, W. Characteristics and culture conditions of a bioflocculant produced by Penicillium sp. Biomed. Environ. Sci. 2010, 23, 213-218. [CrossRef]

(C) 2017 by the authors. Licensee MDPI, Basel, Switzerland. This article is an open access article distributed under the terms and conditions of the Creative Commons Attribution (CC BY) license (http://creativecommons.org/licenses/by/4.0/). 